\title{
The Revenue and Regional Expenditure in Aceh Province: Vector Error Correction (VEC) Approach
}

\author{
Asnawi $^{1}$, Naufal Bachri ${ }^{2}$, Rasyidin ${ }^{3}$ and Aiyub $^{4}$ \\ \{asnawi@unimal.ac.id,naufal@unimal.ac.id,aiyub@unimal.ac.id\} \\ ${ }^{1}$ Department of Economics, Malikussaleh University, Indonesia \\ ${ }^{2}$ Department of Management Science, Malikussaleh University, Indonesia \\ ${ }^{3}$ Department of Political Science, Malikussaleh University, Indonesia \\ ${ }^{4}$ Department of Public Administration, Malikussaleh University, Indonesia
}

\begin{abstract}
The purpose of this research is to analyze the correlation between revenue and regional expenditure in Aceh Province. The research uses time series data for the period 1985 to 2017. The Vector Error Correction Model (VECM) are used to analyze the correlation between revenue and regional expenditure. The results show that the revenue and regional expenditure affect economic growth in the long run. Moreover, in the short run, it shows that the economic growth also affects revenue growth and regional expenditure in Aceh Province. In regard to the finding, there is causality effect between economic growth, revenue, and regional expenditure.
\end{abstract}

Keywords: economic growth, revenue, regional expenditure

\section{Introduction}

The Regional Revenue and Expenditure Budget (APBD) consist of revenue and expenditure. The aim of setting the APBD in the province of Aceh is to encourage economic growth, increase the application of labor and maintain price stability. In order to achieve the goals of APBD, the implementation of APBD is expected to achieve stability in terms of revenue and expenditure. However, the APBD of Aceh is not always balanced because there was a deficit of Rp. 475.46 billion in 2015, and there was an excess (foreign exchange) of Rp. 244.85 billion in 2016, and was also in deficit by Rp. 1,867.77 Trillion (Aceh, 2017).

The Regional Revenue and Expenditure Budget of Aceh Province tends to be unbalanced because it de depends on central transfer funds (the principles of decentralization) by $90 \%$ and very few revenues come from Regional revenue which is only $10 \%$ of them. The Regional Expenditures consist of indirect (routine) and direct (development) expenditure which are greater for indirect expenditures by $60 \%$ or it is only $40 \%$ for development expenditure from the total of it (Aceh, 2017). The sources of revenue and expenditure in the unbalanced APBD ultimately have little impact on achieving the objectives of the APBD stipulation in Aceh Province. The study aims to analyze the causal correlation between Regional Revenue and Expenditure in the Regional Revenue and Expenditure Budget (APBD) of Aceh Province.

\section{Literature Review}

\subsection{Theory of Fiscal Relationship}

There are several studies on the fiscal relationship between state revenues and expenditures in the world of academia (Furstenberg, Green and Jeong, 1985; Anderson, Wallace and Warner, 1986; Blackley, 1986). They examined the expenditures deficit in the 
United States. Fiscal research at the provincial level was reviewed by (Manage and Marlow, 1986; Ismail, 1987; Azlan et al., 2014) (Manage and Marlow, 1986) examined the relationship between state revenues and expenditure at the provincial level by using directional causality models. While (Ismail, 1987; Azlan et al., 2014) examined the growth of expenditures generally faster than economic growth.

In addition, the study of (Dickey and Fuller, 1979; Fasano and Wang, 2002) examined the spend-revenue hypothesis, revenue-spend hypothesis, and the bi-directional causality hypothesis by using data from the Gulf Cooperation Council (GCC) state. The GCC consists of Bahrain Kuwait, Oman, Qatar, Saudi Arabia, and the United Arab Emirates. GCC uses time series data with Granger and VECM methods. In Bahrain, the United Arab Emirates and Oman support the revenue spend hypothesis.

In addition, the causal relationship between revenues and expenditures in Qatar, Saudi Arabia, and Kuwait proves the fiscal synchronization hypothesis. In Kuwait and Saudi Arabia, there is a significant causal relationship between expenditures and revenues. (Abdul Karim and Mokhtar, 2005) examine the relationship between revenue and expenditure in Malaysia. It shows that the revenues significantly relate to the tangible expenditures in the partnership area. Furthermore, Gross Domestic Products influence the growth of expenditures both at the level of partnership or State.

\subsection{Economic Growth (Gross Domestic Products)}

Gross Domestic Product is the amount of added value produced by all business units of economic activity in an area or region in a certain period. The economic growth of a region can increase tax and regional revenues. The economic growth in the regions influences the increasing of Regional expenditure. Economic growth is influenced by the Regional revenue budget(Adi, 2006).

\subsection{Pendapatan Asli Daerah (Own Source Revenue)}

Own Source Revenue (PAD) is the revenue that shows the ability of an area to collect sources of funds to finance routine and development activities. Own source revenue (PAD) is a source of revenue that must always be continuously driven by growth. The Regional revenue can increase Regional expenditure (Munir and Mahdar, 2014). Own source revenue can be influenced by Regional economic growth. On the other hand, Own source revenue can also be influenced by development expenditures(Adi, 2006).

\subsection{Regional Expenditure (Budget Expenditure)}

Regional expenditure is a decrease in economic benefits during the accounting period in the form of cash outflows or asset depletion, or the occurrence of debt which results in reduced equity funds, other than those related to distribution to equity fund participants. Regional expenditure will increase if the economic growth and revenue increases. In addition, (Adi, 2006) said that the higher regional expenditure, the higher the economic growth and regional revenue.

\section{Methodology}

This study uses annual data (time series) from 1985 to 2017 around 32 years. The research data are obtained from the Central Burea of Statistics and Aceh Dalam Angka. The data for each variable is the Regional Revenues (PND), Regional Expenditures (BJD) and the 
Gross Regional Domestic Products (PDRB) of Aceh Province in which are transformed in the form of Logs. The data are analyzed using Eviews software. There are two data tests before conducting Granger and Vector Error Correction (VEC) analysis, namely the Root Test Unit and the Cointegration Test. These tests are carried out to see the data quality and become a condition before using Granger and Vector Error Correction analysis.

\section{Results And Discussion}

The results are obtained from the Unit root test, Cointegration test, Granger test, and Vectors error correction model test. Furthermore, the discussion of the study results as follow:

\subsection{Unit Root Test}

The unit root test is to avoid false regression from time series data within the period 1985-2017. The unit root test results using the Augmented Dickey-Fuller (ADF) method in this study are:

Table 1. ADF Unit Root Test Method

\begin{tabular}{lcccc}
\hline Variabel & Unit Root Test & ADF Test Statistic & $\begin{array}{c}\text { Critical Value } \\
\mathbf{( 5 \% )}\end{array}$ & Keterangan \\
\hline \multirow{2}{*}{ PND } & Level I (0) & 0.466044 & -2.957110 & No Stationer \\
\cline { 2 - 5 } & First Different I(I) & -6.585668 & -2.960411 & Stationer \\
\hline \multirow{2}{*}{ BJD } & Level I (0) & -0.384464 & -2.957110 & No Stationer \\
\cline { 2 - 5 } & First Different I(I) & -6.699355 & -2.960411 & Stationer \\
\hline \multirow{2}{*}{ PDRB } & LevelI (0) & -1.287895 & -2.960411 & No Stationer \\
\cline { 2 - 5 } & First Different I (I) & -8.951736 & -2.960411 & Stationer \\
\hline
\end{tabular}

Mark * $\left.{ }^{* *}\right)$ rejects H0 which indicates the significant stationary variable at $1 \%$ and $5 \%$

Table 1 shows the unit root test of the research variables. PND shows that the ADF test statistical value is 0.46604 or lower than the critical value by $2.957110(\alpha=5 \%)$ at the level I (0). This means the data is not stationary. At the level of First Different I (I) shows that the value of the ADF Statistical Test is 6.585668 or higher than that the critical value of 2.960411 $(\alpha=5 \%)$. It means that the data is stationary. BJD indicate that the ADF test statistic value is 0.384464 which is lower than the critical value of $2.957110(\alpha=5 \%)$ at the level I (0). This means that the data is not stationary. At the First Different I (I) level shows that the ADF Test Statistics value is 6.699355 or higher than the critical value of $2.960411(\alpha=5 \%)$. This means that the data is stationary, while the GRDP and the ADF test statistic value is 1,287895 or lower than the critical value of $2,957110(\alpha=5 \%)$ at the level I (0). This means that the data is not stationary. At the First Different I (I) level shows that the ADF Test Statistics value is 8.951736 or higher than the critical value of $2.960411(\alpha=5 \%)$. It means that the data is stationary.

\subsection{Cointegration Test}

Cointegration test means that there is a long-term relationship (balance). (Johansen and Juselius, 1990) cointegration test uses the Trace statistical test (raceTrace) and Max statistical test (axMax) both values from the statistical test are compared to the critical value of (Said and Dickey, 1984; Osterwald-Lenum, 1992) at 5\% confidence level.

Table 2. Johansen Cointegration Test

\begin{tabular}{ccccc}
\hline $\begin{array}{c}\text { Hypothesized Number } \\
\text { of CE(s) }\end{array}$ & $\lambda_{\text {Trace }}$ & $\lambda_{\text {Max }}$ & $\begin{array}{c}\text { Critical value } \\
(\mathbf{0 . 0 5 )}\end{array}$ & $\begin{array}{c}\text { Critical value } \\
(\mathbf{0 . 0 5 )}\end{array}$ \\
\hline None * & 38.34320 & 29.37786 & 35.01090 & 24.25202 \\
\hline At most 1 & 8.965341 & 5.196827 & 18.39771 & 17.14769 \\
\hline At most 2 & 3.768514 & 3.768514 & 3.841466 & 3.841466 \\
\hline
\end{tabular}


Information: * Significant value is $5 \%$. The critical values are obtained from OsterwaldLenum (1992)

Based on the cointegration test results in Table 2, through Trace Statistics shows that there are two vector equations which cointegrate at a significant level of $5 \%$. Furthermore, through max-eigen statistics with the results of the two vector equations cointegrate at a significant level of $5 \%$. This is a long-term relationship in the variables of PND, BJD, and PDRB where the null hypothesis is rejected, with the statistical trace and one vector equation cointegrated with max-eigen stastistics.

Table 3. VECM Version Granger Test

\begin{tabular}{lcccccc}
\hline $\begin{array}{c}\text { Variabel } \\
\text { Dependen }\end{array}$ & Uji $t$ & \multicolumn{5}{c}{ Uji $F$} \\
\hline & $\mathrm{e}_{\mathrm{t}-1}$ & $\Delta \mathrm{PND}$ & $\Delta \mathrm{BJD}$ & $\Delta \mathrm{PDRB}$ & $\mathrm{R}^{2}$ & $\mathrm{~F}$ \\
\hline \multirow{2}{*}{$\Delta \mathrm{PND}$} & -1.53117 & & 2.34911 & $27.1449^{*}$ & 0.481969 & 2.924075 \\
& $(0.10656)$ & & $(0.1362)$ & $(0.0000)$ & & \\
\hline \multirow{2}{*}{$\Delta \mathrm{BJD}$} & 1.05501 & 0.08344 & & $6.94610^{*}$ & 0.187754 & 1.502500 \\
\hline \multirow{2}{*}{$\Delta$ PDDB } & $(0.01738)$ & $(-0.7747)$ & & $(0.0133)$ & & \\
\hline & -4.85032 & 0.11510 & 0.51027 & & 0.605190 & 9.963625 \\
\hline
\end{tabular}

Mark $* * *, * *$ and $*$ are significant at $1 \%, 5 \%$ and $10 \%$. The value in parentheses is the pvalue of the statistical test

\subsection{Granger Test}

Table 3 shows that the statistical value for the GRDP relationship with PND is 27.1449 * with a significance level of $1 \%$. This value means that there is a significant and positive relationship between GRDP and PND. In the short term, if the economic growth increases then the revenue growth also increases. In return, if the growth of revenue increases then the economic growth will also increase. In the province of Aceh, the growth of the real sector such as the development of industry, agriculture, plantations, and other sectors can increase regional revenue growth. Reducing economic activity will reduce economic growth.

The t-statistic value for the GRDP relationship with BJD is 6.94610 * with a significance level of 5\%. The value indicates a significant and positive relationship between GRDP and $B J D$. In the short term, if the economic growth increases, the regional expenditure will also increase. Conversely, if the regional expenditure increases, it can increase economic growth. Contextually, the real sector growth can increase the amount of tax revenue for the region. This tax is an income for regional governments.

The value of t-statistic of PDRB is 4.85032 with the significant value of $5 \%$. This value means that the economic growth (PDRB) affects the revenues (PND) and Regional expenditures (BJD) in the long-term. The PND t-statistic value is 1.53117 with a probability level of 0.10656. It means that the Regional revenue does not have a significant effect in increasing the economic growth. The BJD t-statistic value is 1.05501 with a probability level of 0.17380 . This means that regional expenditure does not affect economic growth. In the long run, only economic growth has a significant effect on Regional revenue and Expenditure. However, Regional revenue and expenditure have no significant effect on the economic growth in the Aceh province. This study is not in line .with the opinion of (Azlan et al., 2014) who say that the growth of expenditure can affect the economic growth.

Thes findings give an indication that economic growth has been determined by Regional development expenditure factors. The increasing percentage of development expenditure shows the concern of the Aceh Province to improve the Regional economy. The Regional expenditures so far have been realized for the construction of infrastructure and infrastructure 
facilities as well as increasing the services of taxes and levies will increase the Regional Revenues of the Aceh Province. The expenditure development is not only intended for the development of industrial infrastructure, but also for various service infrastructures that are directly related to the community services. The efforts to increase PAD through levies or taxes must be balanced with the seriousness of regional governments to improve the quality of public services. All of these things must be in accordance with the principles of public policy as stated by Thomas R. Dye "What has the government chosen to do or not to do".

\section{Conclusion}

In the short term, the growth of GRDP in Aceh Province increases the regional revenue growth. Preferably, Regional revenue growth increases GDP growth. In addition, the growth of GRDP increases the Regional expenditure growth. Conversely, the growth of Regional expenditure increases the growth of GDP. In the long-term, it produces a different relationship and only GRDP growth increases the Regional revenue and expenditure while the Regional revenue and expenditure do not influence the growth of GRDP.

\section{References}

[1] Abdul Karim, Z. and Mokhtar, A. (2005) 'Hubungan antara hasil dengan perbelanjaan: bukti empirikal kerajaan persekutuan dan kerajaan negeri di malaysia', IJMS 12, 12(2), pp. $145-170$.

[2] Aceh, B. P. S. P. (2017) Aceh Dalam Angka, tahun : 1985-2017. aceh.

[3] Adi, P. H. (2006) 'Hubungan Antara Pertumbuhan Ekonomi Daerah, Belanja Bidang: Akuntansi Sektor Publik', in Simposium Nasional Akuntansi IX Padang, p. 37. Available https://www.researchgate.net/profile/Priyo Adi/publication/308650586 HUBUNGAN _ANTARA_PERTUMBUHAN_EKONOMI_DAERAH_BELANJA_PEMBANGUN AN_DAN_PENDAPATAN_ASLI_DAERĀ $\bar{H} /$ links/57ea3f0108aef8bfcc98d646.pdf.

[4] Anderson, W., Wallace, M. S. and Warner, J. T. (1986) 'Government and Taxation: Spending What Causes What ?', Southern Economic Journal, 52(3), pp. 630-639.

[5] Azlan, M. N., Halimah, M. K., Shafinas, S. Z. and Daud, W. M. (2014) 'Polarizability and optical basicity of Er3+ ions doped tellurite based glasses', Chalcogenide Letters, 11(7), pp. 319-335.

[6] Blackley, P. R. (1986) 'CAUSALITY BETWEEN REVENUES AND EXPENDITURES AND THE SIZE OF THE FEDERAL BUDGET', PUBLIC FINANCE QUARTERLY, 14(2), pp. 139-156.

[7] Dickey, D. A. and Fuller, W. A. (1979) 'Distribution of the Estimators for Autoregressive Time Series with a Unit Root', Journal of the American Statistical Association, 74(366a), pp. 427-431. doi: 10.2307/2286348.

[8] Fasano, U. and Wang, Q. (2002) Testing the relationship between government spending and revenue:evidance from GCC Countries. WP/02/201.

[9] Furstenberg, G. M. Von, Green, R. J. and Jeong, J.-H. (1985) 'Have Taxes Led Government Expenditures? The United States as a Test Case', Journal of Public Policy, 5(3), pp. 321-348.

[10] Ismail, A. G. (1987) Pertumbuhan Perbelanjaan Awam di Malaysia, 1960-1986.

[11] Johansen, S. and Juselius, K. (1990) 'Maximum likelihood estimation and inference on cointegration - With applications to the demand for money', Oxford Bulletin of Economics and Statistics, 52(2), pp. 169-210. 
[12] Manage, N. and Marlow, M. L. (1986) 'The Causal Relation between Federal Expenditures and Receipts', Southern Economic Journal, 52(3), p. 617. doi: $10.2307 / 1059261$.

[13] Munir, M. and Mahdar, N. M. (2014) 'Pengaruh Pertumbuhan Ekonomi, Pendapatan Asli Daerah dan Dana Alokasi Umum Terhadap Pengalokasian Anggaran Belanja Modal (Studi Kasus pada Kabupaten/Kota di Provinsi Jawa Tengah)', KALBISSOCIO Jurnal Bisinis dan Komunikasi, 3(2), pp. 30-37. doi: 10.1007/s13398-014-0173-7.2.

[14] Osterwald-Lenum, M. (1992) 'A Note with Quantiles of the Asymptotic Distribution of the Maximum Likelihood Cointegration Rank Test Statistics1', Oxford Bulletin of Economics and Statistics, 54(3), pp. 461-472. doi: 10.1111/j.14680084.1992.tb00013.x.

[15] Said, S. E. and Dickey, D. A. (1984) 'Testing for Unit Roots in Autoregressive-Moving Average Models of Unknown Order', Biometrika, 71(3), pp. 599-607. doi: $10.2139 /$ ssrn.2882101. 